\title{
PENANGGULANGAN KEKERASAN SEKSUAL TERHADAP ANAK DI BENGKULU
}

\author{
Linda Safitra ${ }^{1}$, Novliza Eka Patrisia ${ }^{2}$, Fitria Yuliani ${ }^{3}$ \\ ${ }^{1}$. Program Studi Sosiologi FISIP Universitas Muhammadiyah Bengkulu \\ lindasafitra@umb.ac.id
}

\begin{abstract}
ABSTRAK
Penelitian ini bertujuan untuk mengetahui dan menganalisis Penanggulangan Kekerasan Seksual Oleh Dinas Pemberdayaan Perempuan, Perlindungan Anak, Pengendalian Penduduk dan Keluarga Berencana (DP3A PPKB) Kabupaten Rejang Lebong Provinsi Bengkulu. Kabupaten ini merupakan salah satu kabupaten yang tergolong tinggi angka kekerasan seksualnya, yaitu urutan ke 2 dari 10 kabupaten/kota di Provinsi Bengkulu. Penelitian ini menggunakan metode penelitian kualitatif. Berdasarkan taraf penjelasannya, maka tipe penelitian adalah deskriptif yang lebih mendalam). Data penelitian dikumpulkan melalui teknik observasi, wawancara dan pengumpulan dokumen. Hasil Penelitian menunjukan bahwa terdapat 3 Program penanggulangan Kekerasan Seksual terhadap Anak yang dilakukan oleh DP3A PPKB Kabupaten Rejang Lebong yaitu: Program Satgas Perlindungan Anak Terpadu Berbasis Masyarakat (PATBM), Satgas Perlindungan Perempuan dan Anak (PPA), dan Sistem Informasi Online (SIMFONI). Penanggulangan kekerasan seksual terhadap anak di Kabupaten Rejang Lebong melalui tiga program tersebut tidak berjalan optimal. Terdapat empat kelemahan utama dalam pelaksanaan program yaitu; Kurangnya sumber daya manusia; Belum optimalnya kegiatan pelatihan bagi unsur pejabat di DP3A PPKB, PATBM dan Satgas PPA, Minimnya pelibatan organisasi masyarakat atau lembaga swadaya masyarakat yang bergerak di bidang perlindungan perempuan dan anak; dan Belum adanya koordinasi yang terjalin antara DP3A PPKB Kabupaten Rejang Lebong dengan DP3A PPKB Provinsi Bengkulu.
\end{abstract}

Kata kunci : Penanggulangan, Kekerasan Seksual, Terhadap Anak

\begin{abstract}
This study aims to determine and analyze the Prevention of Sexual Violence by the Office of Women's Empowerment, Child Protection, Population Control and Family Planning (DP3A PPKB) in Rejang Lebong Regency, Bengkulu Province. This district is one of the districts classified as high in the number of sexual violence, which ranks second out of 10 districts / cities in Bengkulu Province. This study used qualitative research methods. Based on the level of explanation, the type of research is descriptive in depth). Research data were collected through observation, interview and document collection techniques. The results of the study show that there are 3 Sexual Violence Prevention Programs for Children conducted by DP3A PPKB Rejang Lebong Regency. That is; The Community-Based Integrated Child Protection Task Force (PATBM) program, the Women's and Child Protection Task Force (PPA), and the Online Information System (SIMFONI). The prevention of sexual violence against children in Rejang Lebong Regency through these three programs is not running optimally. There are four main weaknesses in the implementation of the program namely; Lack of human resources; Not yet optimal training activities for officials in DP3A PPKB, PATBM and PPA Task Force, The lack of involvement of community organizations or non-government organizations engaged in the protection of women and children; and There is no coordination between DP3A PPKB of Rejang Lebong Regency and DP3A PPKB of Bengkulu Province.
\end{abstract}

Keywords: Prevention, Sexual Violence, Children

2. Program Studi Administrasi Publik FISIP Universitas Muhammadiyah Bengkulu novlizaekap@umb.ac.id

3. Program Studi Ilmu Komunikasi FISIP Universitas Muhammadiyah Bengkulu fitriayuliani@umb.ac.id 


\section{PENDAHULUAN}

Anak Indonesia rentan akan tindakan kekerasan seksual. Tiga tahun belakangan masyarakat indonesia dibuat geram akan pemberitaan mengenai tindakan kekerasan seksual terhadap anak. KPAI mengemukakan bahwa ada 218 kasus kekerasan seksual terhadap anak pada tahun 2015, selanjutnya 120 kasus di tahun 2016, dan 116 kasus pada tahun 2017. Peneliti Balai Besar Penelitian Permasalahan dan Pengembangan Kesejahteraan Sosial (B2P3KS), Kementerian Sosial, mengemukakan bahwa 43 persen kasus kekerasan terhadap anak terjadi karena kontens pornografi ( Hermawati, 2016)

Provinsi Bengkulu sempat menjadi pembicaraan dan perhatian nasional bahkan dunia internasional pada tahun 2016 akibat kasus kejahatan luar biasa yaitu pemerkosaan dan pembunuhan terhadap anak perempuan yang berinisial Y-Y yang terjadi Kecamatan Padang Ulak Tanding Kabupaten Rejang Lebong. Kabupaten ini merupakan salah satu kabupaten yang tergolong tinggi kasus kekerasan seksualnya, yaitu urutan ke 2 dari 10 kabupaten/kota di Provinsi Bengkulu. Pada tahun 2018 terdapat 63 kasus kekerasan seksual daerah ini (DP3A PPKB, 2019)

Pemerintah Provinsi Bengkulu memiliki komitmen tinggi dalam penghapusan segala bentuk kekerasan terhadap anak, termasuk Pemerintah Kabupaten Rejang Lebong. Dengan dikeluarkannya Peraturan Bupati (Perbup) No. 65 Tahun 2017 tentang pembentukan Satgas PPA Rejang Lebong dan Perbup No. 76 tahun 2017 tentang Petunjuk Teknis (Juknis) pelaksanaan pembentukan satgas tindak kekerasan terhadap perempuan dan anak. Maka Pemerintah Kabupaten (Pemkab) Rejang Lebong, melalui Dinas Pemberdayaan, Perlindungan Anak Dan Pengendalian Penduduk dan Keluarga Berencana (DP3A PPKB) telah membentuk, Satuan Tugas Perlindungan Anak Terpadu Berbasis Masyarakat (PATBM) Satuan Tugas Penanganan Perempuan dan Anak (Satgas PPA) yang tersebar di beberapa Kelurahan dan Desa Di Kabupaten Rejang Lebong, serta menggunakan Sistem Informasi Online (SIMFONI)

Kementerian PP-PA RI juga pernah memilih Bengkulu sebagai salah satu prioritas pelatihan Satgas PPA, karena masih tingginya angka kekerasan terhadap perempuan dan anak di Bengkulu. Disamping juga dipertimbangkan atas kasus pemerkosaan dan pembunuhan terhadap Y-Y, siswi SMP di Kecamatan Padang Ulak Tanding (PUT) Kabupaten Rejang Lebong serta kasus lainnya yang hingga saat ini masih marak terjadi

Tingginya angka kekerasan seksual terhadap anak Di Kabupaten Rejang Lebong, menuntut kerja keras DP3A-PPKB dalam merumuskan strategi khusus penanggulangan tindak kekerasan seksual terhadap anak di daerah ini. Keberhasilan pembangunan di sebuah daerah ditentukan 
oleh generasi penerus yang berkualitas yang terjamin hak-hak dasarnya terutama hak perlindungan dari perlakuan salah, eksploitasi dan kekerasan serta perlu didukung oleh budayabudaya positif yang berkembang dalam masyarakatnya. Kasus pemerkosaan dan pembunuhan Y-Y di salah satu kecamatan yang ada di Kabupaten Rejang Lebong membuktikan bahwa daerah ini butuh sebuah penanganan khusus agar kasus yang sama tidak terulang lagi di masa yang akan datang. Oleh karena itu peneliti tertarik melakukan penelitian tentang penanggulangan kekerasan seksual terhadap anak oleh Dinas Pemberdayaan Perempuan, Perlindungan Anak, Pengendalian Penduduk, dan Keluarga Berencana Di Kabupaten Rejang Lebong Provinsi Bengkulu

\section{METODE PENELITIAN}

Tujuan penelitian ini adalah untuk mendeskripsikan penanggulangan kekerasan seksual terhadap anak di Kabupaten Rejang Lebong melalui DP3A-PPKB. Informasi yang akan dikumpulkan dalam penelitian ini berkaitan dengan proses Adaptation, Goal attainment, Integration, dan Latency yang dilakukan oleh DP3A-PPKB dalam penanggulangan kekerasan seksual terhadap anak di Kabupaten Rejang Lebong. Berdasarkan tujuan penelitian, maka jenis penelitian yang dipilih adalah penelitian kualitatif. Sesuai dengan pendapat Creswell (2013:415). Penelitian ini nantinya akan membangun gambaran holistik yang kompleks; menganalisis kata-kata; melaporkan pandangan detail dari Informan Penelitian; dan melaksanakan studi tersebut dalam setting atau lingkungan yang alami. Hasilnya nanti akan menggambarkan secara mendalam mengenai strategi yang dilakukan oleh DP3A-PPKB berdasarkan fakta-fakta yang tampak sebagaimana adanya di lokasi penelitian.

Permasalahan penelitian diawali melalui identifikasi satu kasus yang spesifik yaitu kasus pemerkosaan dan pembunuhan anak perempuan Y-Y di Kecamatan Padang Ulak Tanding Kabupaten Rejang Lebong. Daerah ini menempati posisi tertinggi angka kekerasan seksual sekabupaten di Provinsi Bengkulu. Atas dasar inilah peneliti tertarik untuk mengkaji lebih dalam mengenai strategi penanggulangannya dengan menggunakan tipe penelitian Kualitatif Studi Kasus.

\section{Teknik Penentuan Informan}

Penentuan informan dalam penelitian ini menggunakan teknik Purposive atau bertujuan. Informan utama dalam penelitian ini adalah DP3A-PPKB Kabupaten Rejang Lebong. Terdapat 6 (enam) orang informan dalam penelitian ini yaitu :

1) Sumardiyono, SKM (54 tahun) Kepala Seksi Perlindungan Khusus Anak dan Data Kekerasan Anak DP3A PPKB Kab Rejang Lebong

42 | SUSIOGLLBAL : Jurnal Pemikiran dan Penelitian Sosiologi, Vol. 4, №. I, Desember 2019 
2) Emi Rosita. SE (52 tahun) Kepala Seksi Pemenuhan Hak Anak, Data dan Informasi Anak DP3A PPKB Kab Rejang Lebong

3) Benhur Sitanggang, SKM Kepala Bidang Perlindungan hak perempuan, Perlindungan khusus anak dan pemenuhan hak anak DP3A PPKB Kab Rejang Lebong

4) Heri Wartono (45) Sekretaris DP3A PPKB Kab. Rejang Lebong

5) Yandarwin admin data dan informasi DP3A-PPKB Kab. Rejang Lebong

6) Enny Kurniainy (47 tahun) staf Perlindungan Perempuan dan Anak Kab. Rejang Lebong

\section{Sumber Data}

Sumber data yang diperlukan dalam penelitian tentang Strategi DP3A-PPKB Dalam Penanggulangan Kekerasan Seksual terhadap anak di Kabupaten Rejang lebong adalah sebagai berikut :

1) Data Primer. Data primer penelitian diperoleh secara langsung dari hasil wawancara langsung dengan informan penelitian (tanpa media perantara). Data primer berkaitan dengan informasi dari DP3A-PPKB

2) Data Sekunder. Data sekunder dalam penelitian ini berupa buku, catatan, maupun laporan maupun arsip. Data sekunder nantinya akan diminta dari pemerintahan Kabupaten maupun DP3A-PPKB Kabupaten Rejang Lebong

\section{Teknik Pengumpulan Data}

Dalam penelitian kulitatif sumber data utama adalah kata-kata dan tindakan, selebihnya adalah data tambahan seperti dokumen (Afrizal, 2014 : 20) Pengumpulan data penelitian akan dilakukan melalaui tiga teknik yaitu

1) Teknik observasi.

Observasi awal sudah dilakukan guna melihat kondisi sosial budaya masyarakat, serta melakukan interaksi awal dengan satgas PPA di Kabupaten Rejang Lebong sebagai perkenalan sekaligus sosialisasi awal mengenai rencana kegiatan penelitian yang akan dilakukan. Selanjutnya teknik observasi akan dilakukan sembari melakukan pengumpulan data dengan 2 teknik lainnya, hal ini dilakukan guna membandingkan informasi yang diperoleh dengan realitas yang sesungguhnya, sehingga nantinya bisa menyajikan data penelitian yang valid dan terpercaya.

2) Teknik Wawancara.

Proses wawancara akan dilakukan secara tidak terstruktur dimana peneliti akan mengajukan pertanyaan penelitian terbuka kepada informan penelitian, mendengarkannya 
dengan baik setelah itu baru membentuk pertanyaaan penelitian. TIM Peneliti juga berkomitmen akan meluangkan banyak waktu di lapangan

3) Pengumpulan Dokumen.

Pengumpulan berbagai dokumen dilakukan guna mendukung data primer penelitian. Dokumen-dokumen yang akan dikumpulkan berupa, Dokumen-dokumen terkait kebutuhan penelitian dari DP3A-PPKB Kabupaten Rejang Lebong

\section{Analisis Data}

Proses analisis data dilakukan sejak awal turun ke lapangan, tim akan menganalisis hasil penelitian dengan menyamarkan nama-nama informan, kemudian bekerjasama untuk memaknai data yang telah terkumpul. Analisis data akan dilakukan secara induktif yaitu dari perspektif khusus menuju yang lebih umum, melalui tiga tahap yaitu reduksi data penyajian data, dan penarikan kesimpulan. Analisis hasil penelitian mengacu pada teori Fungsionalisme Struktural Talcott Parsons : AGIL

\section{KERANGKA TEORI/KONSEP}

\section{Kekerasan Seksual Terhadap Anak}

Menurut End Child Prostitution in Asia Tourism (ECPAT) Internasional kekerasan seksual terhadap anak merupakan hubungan atau interaksi antara seorang anak dengan seorang yang lebih tua atau orang dewasa seperti orang asing, saudara sekandung atau orang tua dimana anak dipergunakan sebagai objek pemuas kebutuhan seksual pelaku. Perbuatan ini dilakukan dengan menggunakan paksaan, ancaman, suap, tipuan bahkan tekanan. Kegiatan-kegiatan kekerasan seksual terhadap anak tersebut tidak harus melibatkan kontak badan antara pelaku dengan anak sebagai korban.

Bentuk-bentuk kekerasan seksual itu sendiri bisa dalam tindakan perkosaan ataupun pencabulan (Noviana 2015 :16). Hal ini sesuai dengan penuturan Orange dan Brodwin dalm Jurnal Psikologi Early Prevention Toward Sexsual Abuse On Children yang mengemukakan bahwa kekerasan seksual pada anak adalah pemaksaan, ancaman, atau ketidakberdayaan seorang anak dalam aktivitas seksual. aktivitas seksual tersebut meliputi melihat, meraba, penetrasi (tekanan), pencabulan dan pemerkosaan (Orange dan Brodwin, 2010)

\section{Dampak Kekerasan Seksual Terhadap Anak}

Finkelhor dan Browne (Tower, 2002) mengkategorikan empat jenis dampak trauma yang dialami oleh anak-anak setelah mendapatkan tindakan kekerasan seksual yaitu

44 | SOSIOGLLBAL : Jurnal Pemikiran dan Penelitian Sosiologi, Vol. 4, No. I, Desember 20IS 
1) Pengkhianatan (Betraya), seorang anak membutuhkan perlindungan dari orang tuanya, ketika dia merasa tidak terlindungi oleh orang tuanya maka anak akan cenderung melakukan pengkhianatan, apalagi ketika orang tuanya menganut sistem yang otoriter.

2) Trauma Secara Seksual (Traumatic Sexualization) anak yang mengalami tindakan kekerasan seksual maka akan memiliki kecenderungan trauma dalam melakukan hubungan seksual ketika mereka sudah dewasa nantinya, dan banyak diantara mereka justru terjerumus pada hubungan seksual yang salah misalnya hubungan sesama jenis.

3) Merasa Tidak Berdaya (Powerlessness), trauma mendalam yang dialami oleh anak yang mendapatkan tindakan kekerasan seksual akan mengakibatkan anak mengalami kondisi ketakutan luar biasa, kecemasan yang berkepanjangan. Sehingga pada akhirnya anak akan menutup diri dari lingkungan sosialnya karena kepercayaan diri mereka yang sudah hilang

4) Stigmatization. Anak-anak korban tindakan kekerasan seksual akan mengalami rasa malu, dan memiliki gambaran buruk tentang dirinya sendiri. Mereka sering merasa bahwa mereka sudah tidak sama dengan anak lainnya. Sehingga akan muncul prilaku abnormal dan berujung pada penggunaan obat-obatan terlarang bahasan sampai mengakhiri hidupnya.

\section{Kriminalitas (Kekerasan Seksual Terhadap Anak) Dari Perspektif Sosiologi}

Ilmu sosiologi melihat tindakan kriminalitas termasuk tindakan kekerasan seksual terhadap anak dari sudut pandang yang berbeda dengan ilmu lainnya, sosiologi berupaya menjelaskan tindakan kriminalitas melalui tiga teori yaitu:

1) Teori Strain. Menurut Durkheim satu cara dalam mempelajari masyarakat adalah melihat pada bagian-bagian komponennya dalam usaha mengetahui bagaimana masing-masing berhubungan satu sama lain. Jika bagian-bagian kedalam masyarakat tidak tertata dengan maka masyarakat akan berada dalam keadaan yang membahayakan, keteraturan/ketertiban sosial tidak akan terbentuk. Hal inilah yang memicu tingginya angka kriminalitas di suatu daerah.

2) Teori Penyimpangan Budaya (cultural deviance theories) Teori ini memandang tindakan kriminalitas termasuk kekerasan seksual terhadap anak sebagai seperangkat nilai-nilai yang khas pada lower class (kelas bawah). Tiga teori utama dari cultural deviance theories adalah sebagai berikut: Pertama Theory Social Disorganization Kedua Theory Differential Association. Ketiga Theory Culture Conflict.

3) Teori Kontrol Sosial Menurut teori ini penyimpangan merupakan hasil dari kekosongan kontrol atau pengendalian sosial. Tingginya angka kekerasan seksual di suatu daerah bisa 
dikatakan tidak terlepas dari faktor lemahnya kontrol sosial dalam masyarakat yang bersangkutan, termasuk di lokasi penelitian ini. (Santoso dan Achjani, 2001:66)

\section{Penanggulangan Kekerasan Seksual}

Menurut kamus besar Bahasa Indonesia penanggulangan berasal dari kata "tanggulang" yang berarti menghadapi, mengatasi. Kemudian ditambah awalan "pe" dan akhiran "an" sehingga menjadi "penanggulangan" yang berarti proses, cara, perbuatan menanggulangi. Penanggulangan adalah upaya yang dilaksanakan untuk mencegah, menghadapi, atau mengatasi suatu keadaan mencakup aktivitas preventif dan sekaligus berupaya memperbaiki perilaku seseorang yang telah dinyatakan bersalah. Penanggulangan Kekerasan Seksual terhadap anak dalam penelitian ini diartikan sebagai proses, upaya, dan pendekatan yang dilakukan oleh Satgas PPA guna memutus mata rantai tindakan kekerasan seksual terhadap anak di Desa Padang Ulak Tanding Kabupaten Rejang Lebong.

\section{Landasan Teori}

Penelitian ini akan dianalisis menggunakan teori fungsionalisme struktural yang dikemukakan oleh Talcott Parsons. Menurut Parsons ada empat fungsi penting yang mutlak dibutuhkan bagi semua sistem sosial yang disebutkan sebagai skema AGIL

1) Adaptation : fungsi yang amat penting disini system harus dapat beradaptasi dengan cara menanggulangi situasi eksternal yang gawat, dan system harus bisa menyesuaikan diri dengan lingkungan untuk kebutuhannya

2) Goal attainment ; pencapaian tujuan sangat penting, dimana system harus bisa mendefinisikan dan mencapai tujuan utamanya.

3) Integration: artinya sebuah sistem harus mampu mengatur dan menjaga antar hubungan bagian-bagian yang menjadi komponennya, selain itu mengatur dan mengelola ketiga fungsi (AGIL).

4) Latency :laten berarti system harus mampu berfungsi sebagai pemelihara pola, sebuah sistem harus memelihara dan memperbaiki motivasi pola-pola individu dan cultural ( Ritzer \& Goodman, 2010).

Melalui konsep AGIL ini nantinya akan dianalisis strategi yang dilakukan oleh Satgas PPA di Desa Padang Ulak Tanding dalam penanggulangan kekerasan seksual terhadap anak, strategi tersebut dilihat dari proses adaptasi terhadap lingkungan sosial budaya masyarakat, proses penetapan upaya-upaya guna mencapai tujuan, proses integrasi dengan masyarakat, serta strategi guna perbaikan kondisi sosial dan budaya masyarakat ke arah yang lebih baik. 


\section{PEMBAHASAN}

Tingkat kekerasan seksual terhadap anak di Kabupaten Rejang Lebong hingga bulan Agustus 2019 berjumlah 30 kasus, sementara di sepanjang tahun 2018 terdapat 63 kasus. Data tersebut dapat dilihat perbandinganya dengan jelas pada tabel berikut :

Tabel 1. Data Kekerasan Terhadap Anak di Kabupaten Rejang Lebong Menurut Kecamatan Desember Tahun 2018

\begin{tabular}{clccc}
\hline \hline No & \multicolumn{1}{c}{ Kecamatan } & Bulan Ini & Bulan Lalu & Sampai Dengan Bulan Ini \\
\hline 1 & Curup & 1 & 10 & 11 \\
\hline 2 & Curup Utara & 0 & 4 & 4 \\
\hline 3 & Curup Selatan & 0 & 2 & 2 \\
\hline 4 & Curup Timur & 2 & 10 & 12 \\
\hline 5 & Curup Tengah & 3 & 9 & 1 \\
\hline 6 & Bermani Ulu & 0 & 1 & 10 \\
\hline 7 & Bermani Ulu Raya & 1 & 9 & 0 \\
\hline 8 & Selupu Rejang & - & 9 & 0 \\
\hline 9 & Sindang Kelingi & - & 0 & 0 \\
\hline 10 & Sindang Dataran & - & 0 & 2 \\
\hline 11 & Binduriang & - & 0 & 0 \\
\hline 12 & Padang Ulak Tanding & 1 & 1 & 0 \\
\hline 13 & Sindang Beliti Ilir & 0 & 0 & 0 \\
\hline 14 & Sindang Beliti Ulu & 0 & 0 & 63 \\
\hline 15 & Kota Padang & 0 & 0 & 55 \\
\hline & Jumlah & 8 & & 0 \\
\hline \hline
\end{tabular}

Sumber : DP3A PPKB Kab. Rejang Lebong, 2018

Tabel 2. Data Korban Kekerasan Terhadap Anak Tahun 2019

\begin{tabular}{clc}
\hline \hline No & Bulan & Jumlah Kekerasan \\
\hline 1 & Januari & 2 \\
\hline 2 & Februari & 8 \\
\hline 3 & Maret & 6 \\
\hline 4 & April & 2 \\
\hline 5 & Mei & 3 \\
\hline 6 & Juni & 6 \\
\hline 7 & Juli & 3 \\
\hline & Jumlah & 30 \\
\hline \hline
\end{tabular}

Sumber : DP3A PPKB Kab. Rejang Lebong, 2019 
Meskipun kedua tabel ditampilkan dengan format yang berbeda, dimana tabel pada tahun 2018 menghitung kasus berdasarkan jumlah yang terjadi di setiap kecamatan, sementara tabel pada tahun 2019 menggunakan perhitungan kasus yang terjadi setiap bulannya. Namun hal ini menunjukkan bahwa kasus kekerasan seksual di Kabupaten Rejang Lebong setengah tahun 2019 sudah mencapai 30 kasus atau setengah jumlah kasus di tahun 2018 yang bisa saja terus bertambah menjadi sama banyak dengan jumlah kasus di tahun sebelumnya. Namun pihak DP3A PPKB Kabupaten Rejang Lebong melalui Kepala Seksi Perlindungan Khusus Anak dan Data Kekerasan Anak, Sumardiyono, SKM melihat hal tersebut sebagai hal yang positif, karena peningkatan angka tersebut mengindikasikan adanya kesadaran dari masyarakat di Kabupaten Rejang Lebong untuk melaporkan tindak kekerasan seksual terhadap anak yang mereka alami. Walaupun demikian, bukan berarti mereka tidak berbuat apa-apa dengan melihat kasus kekerasan seksual yang angkanya terus bertambah setiap bulan. Pihak DP3A PPKB mengakui telah membuat beberapa program sebagai upaya penanggulangan kasus kekerasan seksual anak di Kabupaten Rejang Lebong, yaitu :

1) Satgas Perlindungan Anak Terpadu Berbasis Masyarakat (PATBM) sejak tahun 2016.

2) Penetapan Satuan Tugas Perlindungan Perempuan dan Anak (Satgas PPA)

3) Pemanfaatan SIMFONI PPA (Sistem Informasi Online Perlindungan Perempuan dan Anak).

Hanya saja kemudian dalam pelaksanaannya terdapat beberapa kelemahan yang membuat program-program tersebut belum dapat berjalan dengan optimal. Berikut adalah dua kelemahan terbesar dalam pelaksanaan program-program tersebut :

\section{1) Kurangnya Sumberdaya Manusia di DP3A PPKB Rejang Lebong}

Berdasarkan hasil pengamatan tim pengumpul data di lapangan terlihat dengan jelas dalam struktur organisasi Dinas Pemberdayaan Perempuan Perlindungan Anak, Pengendalian Penduduk dan Keluarga berencana tidak memiliki tenaga ahli khusus terkait dengan penanganan kekerasan seksual terhadap anak. Hal ini terlihat dari gelar kesarjanaan yang dimiliki oleh orang-orang yang menempati struktur organisasi terkait bidang penanganan kekerasan seksual terhadap anak di DP3A PPKB. Berikut nama beserta gelar kesarjanaannya:

a) Heri Wartono, SKM, MM (45) Sekretaris DP3A PPKB

b) Sumardiyono, SKM (54 tahun) Kepala Seksi Perlindungan Khusus Anak dan Data Kekerasan Anak

c) Emi Rosita. SE (52 tahun) Kepala Seksi Pemenuhan Hak Anak, Data dan Informasi Anak

40 | STSIOGLOBAL : Jurnal Pemikiran dan Penelitian Sosiologi, Vol. 4, No. I, Desember 2019 
d) Benhur Sitanggang, SKM Kepala Bidang Perlindungan hak perempuan, Perlindungan khusus anak dan pemenuhan hak anak

e) Yandarwin admin data dan informasi DP3A-PPKB

f) Enny Kurniainy, SH (47 tahun) staf Perlindungan Perempuan dan Anak

Permasalahan kekerasan seksual terhadap anak tentunya bukan terkait masalah biologi saja, hal ini juga merupakan permasalahan psikis dan sosial yang perlu dimusnahkan dari akarnya. Oleh karena itu penanggulangan kekerasan seksual terhadap anak tentu juga membutuhkan ahli sosial dan psikolog yang mampu menganalisis dan merancang program-program penanggulangan sesuai dengan kajian bidang sosial. Namun dari nama-nama di atas terlihat tidak ada satu pun yang memiliki latar belakang pendidikan sarjana sosial maupun sarjana psikologi. .

Sehingga dari hasil penamatan ini dapat dikatakan bahwa permasalahan utama tidak optimalnya pelaksanaan program bukanlah karena kekurangan dana, namun karena kekurangan sumber daya manusia untuk merencanakan program-program/ kegiatan terkait penanggulangan kekerasan seksual terhadap anak. Hal ini dibenarkan oleh Sumardiyono Kepala Seksi Perlindungan Khusus Anak dan Data Kekerasan Anak :

Kurangnya SDM (saat ini DP3A memiliki 3 Kepala seksi dan 3 orang staf) menyebabkan perencanaan kegiatan menjadi kurang matang, bahkan hampir tidak ada kegiatan yang berjalan dengan optimal .Seperti misalnya sosialisasi di 18 desa PATBM tidak dapat berjalan secara rutin setiap bulan karena kurangnya SDM di DP3A yang dapat berkunjung ke lokasi tersebut. Hal ini lah yang berujung pada kekurangan anggaran di DP3A PPKB, bagaimana mereka mau mendapatkan anggaran/dana kegiatan jika proposal kegiatan tidak naikan ke pusat/provinsi.

Enny Kurniainy yang mengisi posisi staf PPA menjelaskan bahwa pemangkasan anggaran terjadi pada tahun 2018 untuk masa kerja tahun 2019. Hal tersebut terjadi karena pada tahun 2017 tidak banyak program yang mereka jalankan sehingga dianggap tidak mampu menyerap anggaran yang sudah disediakan. Hal ini, senada dengan yang disampaikan oleh Sumardiyono, kurangnya kegiatan di bidang PPA disebabkan oleh kurangnya sumber daya manusia yang melakukan perencanaan untuk pengembangan program karena sumber dayanya yang pada tahun 2017 hanya berjumlah empat orang harus fokus pada pendampingan korban.

2) Tidak adanya kegiatan pelatihan bagi unsur pejabat di DP3A PPKB, PATBM dan Satgas PPA di Kabupaten Rejang Lebong 
Penetapan PATBM yang melibatkan dua desa pada pertama kali penetapannya di tahun 2016 dan selalu bertambah setiap tahun sehingga menjadi 18 desa pada tahun 2018 ternyata tidak diimbangi dengan pembinaan atau pelatihan yang memadai. Dari 18 desa yang ditunjuk menjadi desa binaan, baru dua desa yang mendapatkan pelatihan, yaitu desa Sidorejo dan Sumber Urip yang ditetapkan sebagai desa binaan PATBM pertama kali pada tahun 2016.

Bahkan dari bidang Perlindungan Perempuan dan Anak di DP3A PPKB Kabupaten Rejang Lebong sendiri, sejak terbentuk di tahun 2017 hingga saat ini hanya ada satu orang, yaitu Kepala Bidang Perlindungan Perempuan dan Anak, Benhur Sitanggang, SKM, yang sudah menjalani pelatihan mengenai penanggulangan kasus kekerasan seksual terhadap anak yang diadakan oleh pihak kementerian. Setelah mengikuti pelatihan pun, beliau belum pernah menyampaikan atau meneruskan kembali informasi yang didapat selama pelatihan kepada kepala-kepala seksi dan staf bidang PPA di DP3A PPKB Kabupaten Rejang Lebong.

Pada saat dikonfirmasi ke Sumardiyono, SKM, selaku Kasi Perlindungan Khusus Anak dan Data Kekerasan Anak mengenai hal ini, beliau menyatakan bahwa memang programprogram yang dibuat dalam pelaksanaannya terkendala oleh jumlah sumber daya manusia di DP3A PPKB Kabupaten Rejang Lebong yang sangat minim. Sehingga setiap tahunnya tidak bisa fokus kepada perencanaan pembinaan kelompok seperti bimtek atau pelatihan khusus karena harus lebih fokus kepada upaya pendampingan anak sebagai korban kekerasan seksual. Sementara mengenai pelatihan bagi unsur-unsur pejabat yang ada di dalam dinas sendiri belum pernah ia dapatkan, terlebih karena ia baru menempati posisinya tersebut pada bulan April 2019.

Selain itu, Sumardiyono menambahkan bahwa lokasi PATBM yang tersebar cukup jauh antar satu dan lainnya cukup menyulitkan mereka dalam melakukan kunjungan karena ini dapat memakan waktu yang cukup lama dan biaya operasional yang tidak sedikit. Sementara bila mereka terlalu lama meninggalkan kantor, ini akan berdampak pada pelayanan yang diberikan. Belum lagi anggaran yang diberikan ke pihak DP3A PPKB telah mengalami pemangkasan, sehingga untuk mengumpulkan seluruh anggota desa binaan PATBM dan Satgas PPA yang berjumlah lima orang di setiap desa pun menjadi kendala yang cukup mengganggu.

Mengenai pendanaan, Enny Kurniainy yang mengisi posisi staf PPA sejak tahun 2017 menjelaskan bahwa pemangkasan anggaran terjadi pada tahun 2018 untuk masa kerja tahun 2019. Hal tersebut terjadi karena pada tahun 2017 tidak banyak program yang mereka jalankan sehingga dianggap tidak mampu menyerap anggaran yang sudah disediakan. 
Padahal, senada dengan yang disampaikan oleh Sumardiyono, kurangnya kegiatan di bidang PPA disebabkan oleh kurangnya sumber daya manusia yang melakukan perencanaan untuk pengembangan program karena sumber dayanya yang pada tahun 2017 hanya berjumlah empat orang harus fokus pada pendampingan korban.

3) Minimnya Pelibatan Organisasi Masyarakat atau Lembaga Swadaya Masyarakat yang Bergerak di Bidang Perlindungan Perempuan dan Anak

Setiap desa binaan PATBM dan Satgas PPA yang dibentuk oleh DP2A PPKB memang melibatkan masyarakat setempat sebagai anggotanya. Hanya saja karena pelatihan yang bisa dikatakan tidak ada, maka keberadaan anggota-anggota ini kemudian bisa dilihat hanya sebagai pelengkap persyaratan dibentuknya PATBM dan Satgas PPA tanpa ada keahlian khusus, meskipun tupoksi dari PATBM dan Satgas PPA dijelaskan dalam surat keputusan yang dikeluarkan.

Menyikapi hal ini, Emi Rosita selaku Kepala Seksi Pemenuhan Hak Anak, Data dan Informasi Anak, menjelaskan bahwa semua anggota PATBM dan Satgas PPA adalah masyarakat setempat, bisa jadi perangkat desanya atau anggota masyarakat. Tetapi karena DP3A PPKB tidak pernah melakukan sosialisasi tentang tugas pokok dan fungsi mereka di dalam masyarakat, maka memang tidak banyak yang mengetahui keberadaan mereka. Belum lagi karena mereka belum diberi pelatihan mengenai pencegahan dan penanggulangan kasus kekerasan seksual, jadi mereka juga tidak bisa optimal dalam menjalankan tugasnya. Pelaporan kasus kekerasan seksual yang terjadi pun masih lebih banyak langsung dimasukkan ke pihak kepolisian.

Selain pelibatan masyarakat setempat, DP3A PPKB Kabupaten Rejang Lebong tidak memiliki jaringan kerjasama dengan pihak organisasi masyarakat atau lembaga swadaya masyarakat yang juga memiliki fokus yang sama. Hal ini disampaikan oleh Sumardiyono yang diamini oleh Emi dan disepakati oleh Enny. Enny menjelaskan bahwa ketiadaan kerjasama ini karena tidak adanya koordinasi atau bentuk ajakan kerjasama dari lembaga-lembaga tersebut.

Kerjasama yang dilakukan oleh DP3A PPKB adalah bentuk kerjasama dalam penanganan kasus setelah kasus terjadi bersama Bapas, Peksos, dan unit PPA dari pihak kepolisian. Hal demikian membuat DP3A PPKB beserta desa binaan PATBM dan Satgas PPA yang mereka bentuk seolah menjadi petarung yang berjuang sendirian dalam upaya pencegahan dan penanggulangan berbagai kasus kekerasan seksual terhadap anak di kabupaten Rejang Lebong. Terlebih lagi desa binaan dan satuan tugas yang mereka belum seluruhnya menjalani 
pelatihan atau bimtek mengenai tupoksi yang harus mereka lakukan di wilayah yang telah menjadi tanggung jawab mereka masing-masing.

Sumardiyono pun mengakui bahwa mereka masih sangat kurang dalam hal jaringan dan komunikasi ke lembaga-lembaga demikian karena sebelumnya memang tidak ada program kerjasama yang diadakan dengan lembaga-lembaga tersebut. Bahkan ia yang baru menjabat sebagai kepala seksi selama lima bulan dan kepala bidangnya yang sudah menjabat selama dua tahun ini belum ada melakukan koordinasi ke DP3A Provinsi Bengkulu sehingga belum mengetahui bagaimana program-program yang mereka buat itu sebaiknya dijalankan.

4) Belum dilakukannya koordinasi yang konsisten dan teratur dari DP3A PPKB Kabupaten dengan DP3A PPKB Provinsi Bengkulu sehingga belum mengetahui bagaimana program-program yang mereka buat itu sebaiknya dijalankan, karena belum adanya pelaporan dan evaluasi terhadap program-program yang telah dilaksanakan selama ini

\section{Analisis Teori menggunakan Konsep AGIL dari Talcott Parson}

AGIL (Adaptation, Goal attainment, Integration, Latency) merupakan empat fungsi penting yang mutlak dibutuhkan bagi semua sistem sosial agar bisa tetap bertahan dalam masyarakat. Begitu pula halnya dengan sistem sosial DP3A PPKB yang berusaha menunjukkan dan mempertahankan keberadaannya di dalam masyarakat melalui program-program yang mereka buat berkenaan dengan penanggulangan kekerasan seksual terhadap anak di Kabupaten Rejang Lebong.

Adaptation merupakan fungsi yang harus dimiliki oleh dinas pemerintahan, sehingga programprogram yang mereka buat dapat menyesuaikan dengan apa yang paling dibutuhkan oleh masyarakat dalam menyelesaikan permasalahan di lingkungan sekitar mereka. Selanjutnya adalah goal attainment dimana pemerintah harus memahami tujuan apa yang ingin mereka capai sebelum mereka membuat sebuah program. Tidak kalah penting, yaitu integration, dimana sebuah sistem, katakanlah disini pemerintah, harus mampu mengatur dan menjaga hubungan antar bagian-bagian yang menjadi komponen dalam keberlangsungan program yang dibuat sehingga dapat memberikan hasil yang maksimal, seperti halnya pemerintah pusat, pemerintah tingkat provinsi, perangkat desa, lembaga swadaya masyarakat, dan anggota masyarakat itu sendiri. Lalu ada pula latency, dimana sistem harus mampu menjalankan fungsi sebagai pemelihara pola dan harus mampu pula memperbaiki pola-pola yang yang ada dalam pelaksanaan program, sehingga saat terjadi kekurangan dalam pelaksanaannya, pemerintah dapat segera mengevaluasi dan mencari solusi atas hal tersebut dengan melakukan perubahan pola.

52 | SGSIOGLOBAL : Jurnal Pemikiran dan Penelitian Sosiologi, Vol. 4, №. I, Desember 2019 
Pada penelitian ini, dapat dilihat bahwa pihak DP3A PPKB Kabupaten Rejang Lebong belum mampu menjalankan keempat fungsi tersebut karena program yang dibuat belum mampu disesuaikan dengan kebutuhan masyarakat. Program-program yang dibuat masih dibuat atas dasar perkiraan dari pihak dinas atas kebutuhan dan kondisi masyarakat. Seperti misalnya program desa binaan PATBM dan Satgas PPA yang sudah ditetapkan di 18 desa dan rencananya akan ditambah menjadi 50 desa pada tahun 2020. Desa binaan dan Satgas tersebut dibentuk karena mereka menganggap itulah program yang paling efektif untuk menanggulangi tindak kekerasan seksual terhadap anak, sementara mereka tidak memfasilitasi desa binaan dan satgas tersebut dengan pelatihan dan bimtek yang memadai. Sehingga tindak kekerasan seksual tetap terjadi karena tidak pernah ada sosialisasi mengenai pencegahan tindak kekerasan seksual tersebut dan untuk penanganan kasus, masyarakat yang mengalami tindak kekerasan lebih memilih untuk melaporkan langsung ke pihak kepolisian daripada satgas yang telah dibentuk.jadi bisa dikatakan program yang dibuat tidak bisa beradaptasi untuk mengakomodir kebutuhan masyarakat.

Tujuan dibentuknya desa binaan PATBM dan penetapan anggota satgas PPA ini adalah mengurangi tindak kekerasan seksual terhadap anak di kabupaten Rejang Lebong. Hanya saja dari data yang terhimpun, ternyata dari tahun 2018 hingga 2019, belum terjadi pengurangan yang signifikan dalam kasus kekerasan seksual terhadap anak. Mengapa hal ini bisa terjadi, tentu karena pemerintah ternyata tidak berupaya dengan serius untuk mewujudkan tujuan tersebut, karena pemerintah masih mengejar kuantitas kelompok daripada kualitas kelompok. Hal tersebut diindikasikan oleh tidak adanya kegiatan pelatihan dan bimbingan teknis yang memadai terhadap desa binaan PATBM dan satgas PPA yang terbentuk, sehingga sudah pasti menyulitkan mereka untuk menjalankan tugas mereka seperti sosialisasi, advokasi, promosi, pembimbingan, dan peningkatan pemenuhan hak-hak perlindungan perempuan dan anak terhadap berbagai tindakan kekerasan. Sementara jumlah desa binaan PATBM dan Satgas PPA selalu ditambah setiap tahunnya.

Pihak DP3A PPKB Kabupaten Rejang Lebong juga lemah dalam menjalin hubungan atau menciptakan integrasi dengan sesama pihak dinas terkait, sekolah-sekolah di Kabupaten Rejang Lebong, dan lembaga-lembaga swadaya masyarakat yang mengurusi bidang serupa. Mereka hanya berhubungan dengan pihak-pihak yang telah ditetapkan oleh instansi seperti Bapas, Peksos, dan Unit PPA Polres Rejang Lebong, dan tidak melakukan upaya atau membangun jaringan dan komunikasi dengan pihak luar, hanya menunggu pihak-pihak luar tersebut yang mendatangi mereka. Sudah bisa dipastikan hingga saat penelitian ini dilakukan tidak ada satupun 
yang mendatangi mereka, kecuali satu kelompok mahasiswa KKN dari Universitas Bengkulu di tahun 2018, dan satu kelompok lainnya di tahun 2019.

Pola-pola demikian tentu bukan malah membangkitkan DP3A PPKB dan program penanggulangan kekerasan terhadap anak, namun justru menyulitkan langkah mereka untuk mencegah dan menanggulangi tindak kekerasan terhadap anak. Sudah waktunya bagi pihak DP3A PPKB Kabupaten Rejang Lebong untuk mengubah pola yang mereka lakukan agar kinerja mereka bisa menjadi lebih optimal dan dapat membuahkan hasil yang maksimal pula.

\section{SIMPULAN}

Berdasarkan hasil penelitian yang didapat selama proses penelitian dapat disimpulkan bahwa

A. Penanggulangan Kekerasan seksual terhadap anak Di Kabupaten Rejang Lebong oleh DP3A-PPKB dilakukan melalui 3 Program sebagai berikut :

1) Satuan Tugas Perlindungan Anak Terpadu (PATBM)

2) Satuan Tugas Perlindungan Perempuan dan Anak

3) Sistem Informasi Online (SIMFONI) DP3A PPKB Kabupaten Rejang Lebong

B. Terdapat beberapa kelemahan yang membuat program-program tersebut belum dapat berjalan dengan optimal. Berikut adalah dua kelemahan terbesar dalam pelaksanaan programprogram tersebut :

1) Kurangnya Sumber Daya Manusia : Permasalahan kekerasan seksual terhadap anak tentunya bukan terkait masalah biologi saja, hal ini juga merupakan permasalahan psikis dan sosial, oleh karena itu juga membutuhkan tenaga ahli dalam bidang sosial dan psikologi.

2) Tidak adanya kegiatan pelatihan bagi unsur pejabat di DP3A PPKB, PATBM dan Satgas PPA di Kabupaten Rejang Lebong : Penetapan PATBM yang melibatkan dua desa pada pertama kali penetapannya di tahun 2016 dan selalu bertambah setiap tahun sehingga menjadi 18 desa pada tahun 2018 ternyata tidak diimbangi dengan pembinaan atau pelatihan yang memadai. Dari 18 desa yang ditunjuk menjadi desa binaan, baru dua desa yang mendapatkan pelatihan, yaitu desa Sidorejo dan Sumber Urip yang ditetapkan sebagai desa binaan PATBM pertama kali pada tahun 2016.

3) Minimnya Pelibatan Organisasi Masyarakat atau Lembaga Swadaya Masyarakat yang Bergerak di Bidang Perlindungan Perempuan dan Anak : DP3A PPKB Kabupaten Rejang Lebong belum memiliki jaringan kerjasama dengan pihak organisasi masyarakat atau lembaga swadaya masyarakat yang juga memiliki fokus yang sama.

4) Belum dilakukannya koordinasi yang konsisten dan teratur dari DP3A PPKB Kabupaten dengan DP3A PPKB Provinsi Bengkulu

54 STSIOGLOBAL : Jurnal Pemikiran dan Penelitian Sosiologi, Vol. 4, No. I, Desember 2019 


\section{DAFTAR PUSTAKA}

Afrizal.(2014). Metode Penelitian Kualitatif: Sebuab Upaya mendukung Penggunaan Penelitian Kualitatif Dalam Berbagai Disiplin Ilmu. Jakarta : PT RajaGrafindo Persada.

Creswell, Jhon W. (2013).Penelitian Kualitatif \& Desain Riset : Memilib Diantara Lima Pendekatan (Edisi Ke-3).

Ritzer, George dan Goodman, Douglas.J, (2010). Teori Sosiologi Modern, Edisi Keenam. Jakarta :Kencana Preneda Media Group.

Kristiani, Ni Made Dwi. (2014). Kejahatan Seksual Terhadap Anak (Perkosaan) Ditinjau dari Perspektif Kriminalogi. Jurnal Magister Hukum Udayana, Vol. 7, No. 3, hh. 377.

Kementerian PPPA.(2012).PRESS RELEASE : Satgas PPA Upaya Preventif Lindungi Perempuan Dan Anak. Siaran Pers Nomor: 44/Humas KPP-PA/05/2016.

Noviana, Ivo.(2015). Kekerasan Seksual Terhadap Anak: Dampak Dan Penanganannya., Jurnal Sosio Informa Vol. 01, No. 1, hh. 15.

Orange dan Brodwin.(2010). Early Prevention Toward Sexual Abuse On Children. Jurnal Psikologi Sugiyono.(2008). Metode Penelitian Kuantitatif, Kualitatif dan R \& D. Bandung: Alfabeta

Santoso Topo \& Zulfa, Eva Achjani. (2001). "Kriminologi”. Jakarta : Rajawali pers.

Tower, Cynthia Crosson.(2002). Understanding Child Abuse and Neglect. Boston : Allyn \& Bacon.

Weber, Marx, Smith, \& Dana M. (2010). Outcomes Of Child Sexual Victimization. Journal Of International Violence, (Online) Vol 26 No.9, hh. 1899-1905. 